\title{
In Vitro Inhibition of Human Plasma and Erythrocyte AChE by Various Drugs
}

\author{
İnsan Plazma ve Eritrosit AChE'nin Çeşitli illaçlarla in Vitro \\ İnhibisyonu
}

\author{
Research Article \\ Mehmet Rıza Kıvanç*, Vedat Türkoğlu, Muhammet Güler, Zehra Başı \\ Department of Chemistry, Faculty of Science, Yüzüncü Yıl University, Van, Turkey.
}

\begin{abstract}
A B STRACT
n the present study, the in vitro effects of eight structurally different antibiotics (cefazolin, kanamycin, gentamicin, clindamycin, ivermectin and ampicillin) and painkiller (metamizole and diclofenac) on human erythrocyte and plasma acetylcholinesterase activity (AChE; EC 3.1.1.7) were investigated. For this, $I C_{50}$ and $K_{1}$ values of the drugs were calculated for determining the inhibition caused by these drugs. Acetylcholinesterase activity was determined spectrophotometrically, according to Ellman's method. Then the enzyme activity exposed to the drugs with different concentrations was measured. AChE activity vs. drug concentration and Mihealis-Menten graphs were obtained. Lastly, $I C_{50}$ and $K_{1}$ values were estimated from these graphs. IC $C_{50}$ values were estimated to be $1.78 \times 10^{-8} \mathrm{M}$ of diclofenac for plasma $\mathrm{AChE}$ and $0.85 \times 10^{-8} \mathrm{M}$ of gentamicin for erythrocyte AChE. $K_{1}$ values were $1.36 \times 10^{-8} \mathrm{M}$ for diclofenac and $1.16 \times 10^{-8} \mathrm{M}$ for gentamicin. Also, $\mathrm{IC}_{50}$ and $\mathrm{K}_{1}$ values for ivermectin, clindamycin, kanamycin, ampicillin were obtained. Diclofenac exhibited the highest inhibitory effect on plasma AChE activity. On the other hand, gentamicin showed the highest inhibitory effect on erythrocyte AChE activity, which seems to be better for inhibition of AChE than those reported previously.
\end{abstract}

\section{Key Words}

Acetylcholinesterase, enzyme inhibition, enzyme assay, medicinal drug, human erythrocyte and plasma, in vitro kinetics.

\section{ÖZET}

u çalışmada; yapısal olarak farklı olan sekiz antibiyotik (sefazolin, kanamisin, gentamisin, klindamisin, ivermektin ve ampisilin) ve ağrı kesicinin (metamizol ve diklofenak) insan eritrosit ve plazma asetilkolinesteraz (AChE; EC 3.1.1.7) enzimi üzerine in vitro etkileri araştırı ımıştır. Bu amaçla; farklı derişimlere sahip ilaçların neden olduğu inhibisyonu belirlemek için ilaçların $I C_{50}$ ve $K_{1}$ değerleri hesaplandı. Asetilkolinesteraz aktivitesi spektrofotometrik olarak Ellman yöntemiyle belirlendi. Daha sonra, ilaçlara maruz kalan enzim aktivitesi ölçüldü. AChE aktivitesine karşı ilaç derişimi ve Michealis-Menten grafikleri çizildi. Son olarak, bu grafikler yardımıyla $I C_{50}$ ve $K_{1}$ değerleri hesaplandı. $I C_{50}$ değerleri, plazma AChE'sine diklofenak için $1.78 \times 10^{-8} \mathrm{M}$ ve eritrosit $A C h E^{\prime}$ sine gentamisin için $0.85 \times 10^{-8} \mathrm{M}$ olduğu belirlendi. $K_{1}$ değerleri ise diklofenak için $1.36 \times 10^{-8} \mathrm{M}$ ve gentamisin için $1.16 \times 10^{-8} \mathrm{M}$ olarak hesaplandı. Ayrıca, ivermektin, klindamisin, kanamisin, ampisilin için IC $\mathrm{C}_{50}$ ve $K_{1}$ değerleri elde edildi. Diklofenak, plazma AChE aktivitesi üzerine gentamisin de eritrosit AChE aktivitesi üzerine en yüksek inhibitör etkisi göstermiştir. Bulunan bu değerlerin daha önce yapılan benzer çalışmalardaki inhibisyon değerlerinden daha yüksek olduğu görülmektedir [1,2].

\section{Anahtar Kelimeler}

Asetilkolinesteraz, enzim inhibisyonu, enzim analizi, tıbbi ilaçlar, insan eritrositi ve plazması, in vitro kinetikleri.

Article History: Received: Feb 17, 2016; Revised: May 25, 2016; Accepted: Jun 20, 2016; Available Online: Jul 31, 2016.

DOI: 10.15671/HJBC.20164420564

Correspondence to: M.R. Kıvanç, Department of Chemistry, Faculty of Science, Yüzüncü Yıl University, Van, Turkey. 


\section{INTRODUCTION}

A cetylcholinesterase (AChE; E.C.3.1.1.7) hydrolyses the neurotransmitter acetylcholine to choline and acetate. Furthermore, AChE balances the impulse transmission at cholorgenic synapses [1-3]. There are two type cholinesterases according to the reaction catalyzed by them. The first one is true AChE and the second one is butyrylcholinesterase [4]. AChE exists in liver, muscle, kidney, spleen, brain, erythrocyte, and chorgenic neurons [57]. AChE belonging to its two forms is found either asymmetric or globular. They change from tissue to tissue [8]. Thus, the previous kinetic studies showed that the active site of AChE consist of two subsites, "esteric" and "anionic" (Scheme 1) [9]. The enzyme generally exists as hydrophilic modes in the brain, muscle and the other tissues, which contains disulfide-linked oligomers with collagenous or lipid-containing structural subunits. Amphipathic AChE dimmers with globular structures are attached to the erythrocyte membrane $[10,11]$.

Pseudocholinesterase (PChE) and acetyl cholinesterase (AChE) are isoforms of cholinesterase (ChE) [12]. AChE and PChE are determined by their substrates and some specific inhibitors can affect their activity [13]. The basic role of AChE is the termination of neurotransmission by hydrolyzing of the neurotransmitter acetylcholine at intern euronal synapses in the brain and neuromuscular junctions [14]. As well-known, plasma cholinesterase is generally found in tissues and plasma. Moreover, it works as assistance of AChE because it can catalyze the hydrolysis of various acetylcholines like AChE [15].

Inhibition of both cholinesterase activities are higher in humans affected by neuro degeneration. Subversive processes that can stimulate the death of neurons are connected with cholinesterase activities. In spite of the fact that AChE and PChE have many inhibitors, most of them are very toxic so they cannot be considered as drugs [16].

Antibiotics are among the most widely used drugs inpatient and outpatient. As these antimicrobial agents are commonly well- tolerated, these drugs have some adverse effects, both dose dependent and idiosyncratic in nature. While diarrhea is generally related reverse effect of them, toxic effects on the center of nervous system may be slightly distinguished [17]. A few factors of drug metabolism can enhance inclination to neurotoxicity like an individual's nutritional condition, partial blood flow and tissue ingression, rate of absorption of the medication, line of drug delivery to target tissue, activation and elimination of the drug along with preservative replies the individual $[18,19]$. There are some other factors that can be involved genetic factors, switched in pharmacokinetics of drug in the event of nephritic deficiency and center of nervous system penetration can be connected with leading neurotoxicity [20]. Drugs have generally shown activator or inhibitor on enzyme systems of the body $[21,22]$.

The objective of this in vitro study was to investigate the effect of eight structurally different drugs i.e., ivermectin, diclofenac, clindamycin, gentamicin, kanamycin, ampicillin, cefazolin, and metamizole on both human plasma and erythrocyte AChE.

\section{MATERIALS AND METHODS}

\section{Chemicals and Reagents}

All drugs i.e., ivermectin, diclofenac, clindamycin, gentamicin, kanamycin, ampicillin, cefazolin and metamizole were purchased from a local pharmacia in Van, Turkey. The structures of these drugs were listed in Table 1. The other chemicals, acetylthiocholineiodide, 5,5'-dithio-2bis-nitrobenzoate (DTNB) and sodium phosphate dibasic $\left(\mathrm{NaH}_{2} \mathrm{PO}_{4} \cdot 2 \mathrm{H}_{2} \mathrm{O}\right)$ were obtained from Sigma Aldrich, Germany. For the experimental studies, a unit of blood with antiquagulant was obtained from the Red Crescent, Turkey.

\section{Preparation of Eryhtrocyte, Plasma and Drugs} Fresh human bloods were firstly centrifuged at $3.000 \mathrm{rpm}$ for $15 \mathrm{~min}$. Plasma and erythrocyte were appropriately collected. Plasma and erythrocyte were stored in the deep freeze for further kinetic studies. Erythrocytes were washed three times with isotonic $\mathrm{NaCl}$ solution and centrifuged at $3.000 \mathrm{rpm}$ then the supernatants 

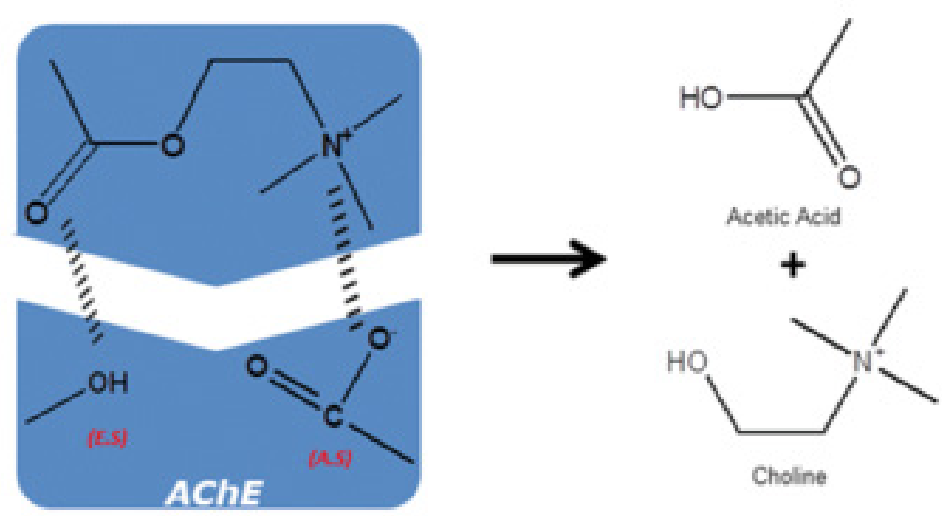

Scheme 1. Representative illustration of AChE.

Table 1. Chemical structures of drugs.<smiles>Cc1c(N(C)OS(C)(=O)=O)c(=O)n(-c2ccccc2)n1C</smiles>

Metamizole<smiles>CC1CC(N)C(OC2CC(N)C(O)C(CO)O2)CC1OC1C(N)C(O)C(O)C(CO)C1O</smiles>

Kanamycin<smiles>CSC1(C)OC(C(NC(=O)C23CCCC2(C)C(C)C3)C(C)Cl)C(O)C(C)(O)C1(C)O</smiles>

Clindamycin

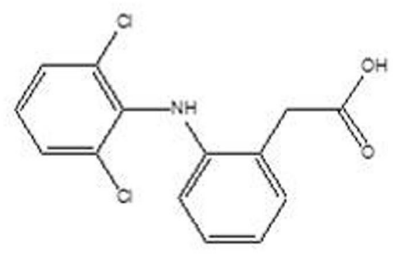

Diclofenac

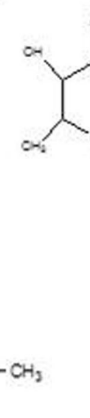

(x).<smiles></smiles>

Cefazolin

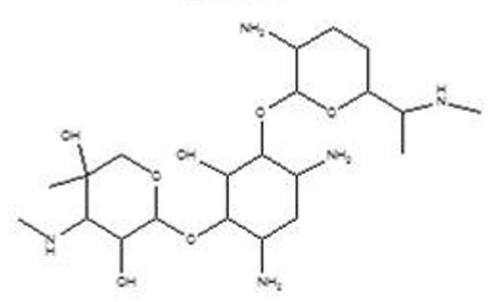

Gentamicin 
Table 2. Drug solutions.

\begin{tabular}{ccc}
\hline & Concentrations, $\left(10^{-8} \mathbf{M}\right)$ & \\
\hline Ivermectin & Drug Plasma & Erythrocyte \\
\hline Diclofenac & $0.354,1.41,3.18$ & $0.354,1.41,3.18$ \\
\hline Clindamycin & $0.236,0.943,2.12$ & $0.236,0.943,2.12$ \\
\hline Gentamicin & $8.91,35.64,80.19$ & $0.594,2.376,5.346$ \\
\hline Ampicillin & $0.375,1.5,3.375$ & $0.375,0.666,1.041$ \\
\hline Kanamycin & $20.2,80.8,181.8$ & $20.2,80.8,181.8$ \\
\hline Cefazolin & $323.8,504.8$ & $1.55,2.11,2.74$ \\
\hline Metamizole & $0.172,1.076,4.303$ & $1.746,6.993,15.74$ \\
& $6.198,13.94$ & $27.97,43.72$ \\
\hline
\end{tabular}

were removed. The washed erythrocytes were hemolyzed with 5 volumes of ice-cold bi-distilled water and then centrifuged at $4^{\circ} \mathrm{C}(20.000 \mathrm{rpm}$ for $30 \mathrm{~min}$ to remove residual intact cells and membranes) [23].

Drug solutions i.e., ivermectin, diclofenac, clindamycin, gentamicin, kanamycin, ampicillin, cefazolin and metamizole were freshly prepared in $56 \mathrm{mM}$ phosphate buffer solution $(\mathrm{pH} \mathrm{8.0)}$ ) at different concentrations that were listed in Table 2.

\section{Activity Assay}

Acetylcholinesterase activity was measured spectrophotometrically with a Shimadzu spectrophotometry UV-(1208), Japan at $25^{\circ} \mathrm{C}$ $412 \mathrm{~nm}$, according to Ellman's method [24]. The assay mixture $(3 \mathrm{ml})$ contained 3 $\mathrm{mM}$ of acetylthiocholine iodide, $10 \mathrm{mM}$ DTNB (5,5'-dithiobis-2-nitrobenzoic acid) and 100 $\mu \mathrm{L}$ of plasma or erythrocyte (2.37 or $1.28 \mathrm{Eu} /$ $\mathrm{ml})$ in $56 \mathrm{mM}$-Na-buffer $\left(\mathrm{NaHPO}_{4} \cdot 2 \mathrm{H}_{2} \mathrm{O}, \mathrm{pH}\right.$ 8) and different concentrations of the drug active compounds were diluted with bi-distilled water or Na-buffer. $K_{m}$ and $V_{\max }$ values were determined by Lineweaver-Burk plots using acetylthiocholineiodide concentrations from 0.05 $\mathrm{mM}$ to $0.15 \mathrm{mM}$. All enzyme activity assays were performed at least four different experiments, each one performed in triplicate. AChE activity values of both erythrocyte and plasma were calculated with the Equation (1):

$$
A=\frac{O D}{13.6} \times \frac{V_{C}}{V_{E}} \times f
$$

A: Activity

OD: Optic density's diversity at $412 \mathrm{~nm}$, per minute $\mathrm{V}_{c}$ : Volume of cuvette

$\mathrm{V}_{\mathrm{E}}$ : Volume of enzyme solution (homogenated plasma or erythrocyte)

f: Dilution factor

13.6: Extinction coefficient for AChE

\section{Detection of $I C_{50}$ and $K_{1}$ Values}

$\mathrm{IC}_{50}$ and $\mathrm{K}_{1}$ values of each drug were calculated from the activity \% vs. inhibitor concentration and the Lineweaver-Burk graph was used for determination of inhibition type and $\mathrm{K}_{1}$ constants. The $K_{1}$ value was determined according to the Equation (2):

$$
\mathrm{V}_{\max }=\mathrm{V}_{\max } /\left(1+\left([\mathrm{I}] / \mathrm{K}_{1}\right)\right)
$$

\section{RESULTS}

Herein, to evaluate the effect of ivermectin, diclofenac, clindamycin, gentamicin, kanamycin, ampicillin, cefazolin, and metamizole on AChE activity, $K_{1}$ and $I C_{50}$ values were calculated 

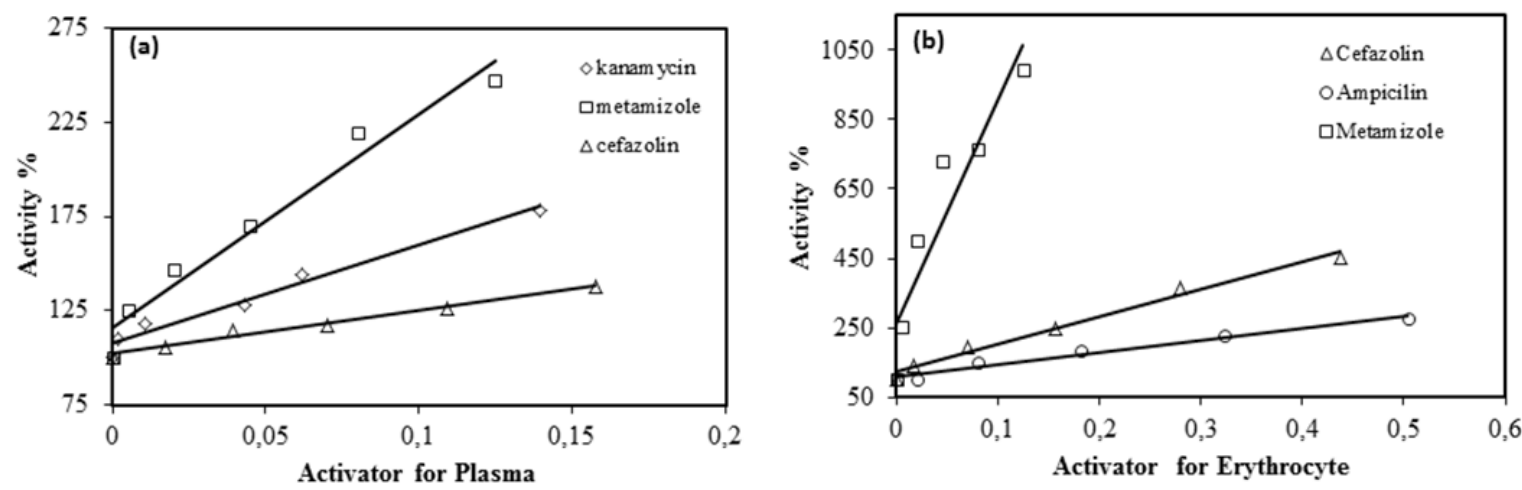

Figure 1. Activator for plasma (a) and erythrocyte (b).

Table 3. The $\mathrm{IC}_{50}$ and $\mathrm{K}_{1}$ values for drug.

\begin{tabular}{|c|c|c|c|}
\hline Sample type & Name of Drug & $I C_{50}\left(10^{-8}\right) M$ & $\mathrm{~K}_{1}\left(10^{-8}\right) \mathrm{M}$ \\
\hline \multirow{8}{*}{ Plasma } & Ivermectin & 1.89 & 1.48 \\
\hline & Diclofenac & 1.78 & 1.36 \\
\hline & Clindamycin & 50 & 804 \\
\hline & Gentamicin & 3.6 & 2.16 \\
\hline & Ampicillin & 140 & 1.56 \\
\hline & Cefazolin & - & - \\
\hline & Kanamycin & - & - \\
\hline & Metamizole & - & - \\
\hline \multirow{8}{*}{ Erythrocyte } & Ivermectin & 1.78 & 1.61 \\
\hline & Diclofenac & 1.39 & 0.99 \\
\hline & Clindamycin & 3.31 & 3.74 \\
\hline & Gentamicin & 0.85 & 1.16 \\
\hline & Kanamycin & 1.65 & 0.87 \\
\hline & Ampicillin & - & - \\
\hline & Cefazolin & - & - \\
\hline & Metamizole & - & - \\
\hline
\end{tabular}

from Lineweaver-Burk and drug concentration vs. activity \%, respectively. They were tested on human plasma and erythrocyte acetylcholinesterase activity. $I_{50}$ for plasma AChE was $1.78 \times 10^{-8} \mathrm{M}$ of diclofenac, $1.89 \times 10^{-8} \mathrm{M}$ of ivermectin, $3.6 \times 10^{-8} \mathrm{M}$ of gentamicin, $50 \times 10$ ${ }^{8} \mathrm{M}$ of clindamycin and $140 \times 10^{-8} \mathrm{M}$ of ampicillin. $\mathrm{IC}_{50}$ for erythrocyte AChE was $0.85 \times 10^{-8} \mathrm{M}$ of gentamicin, $1.39 \times 10^{-8} \mathrm{M}$ of diclofenac, $1.65 \times 10^{-8} \mathrm{M}$ of kanamycin, $1.78 \times 10^{-8} \mathrm{M}$ of ivermectin, $3.31 \times 10^{-8}$
M of clindamycin (Table 3). In all cases, the drugs possessing inhibition effect on both plasma and erythrocyte showed non-competitive inhibition. The drugs showing activator effect on both plasma and erythrocyte AChE are shown in Figure 1.

The type of inhibition caused by the drugs was assessed by Lineweaver-Burk plots which were drawn by using $1 / \mathrm{V}$ vs $1 / \mathrm{S}$ values. $\mathrm{K}_{\text {, constants }}$ were calculated from these graphs and shown in 

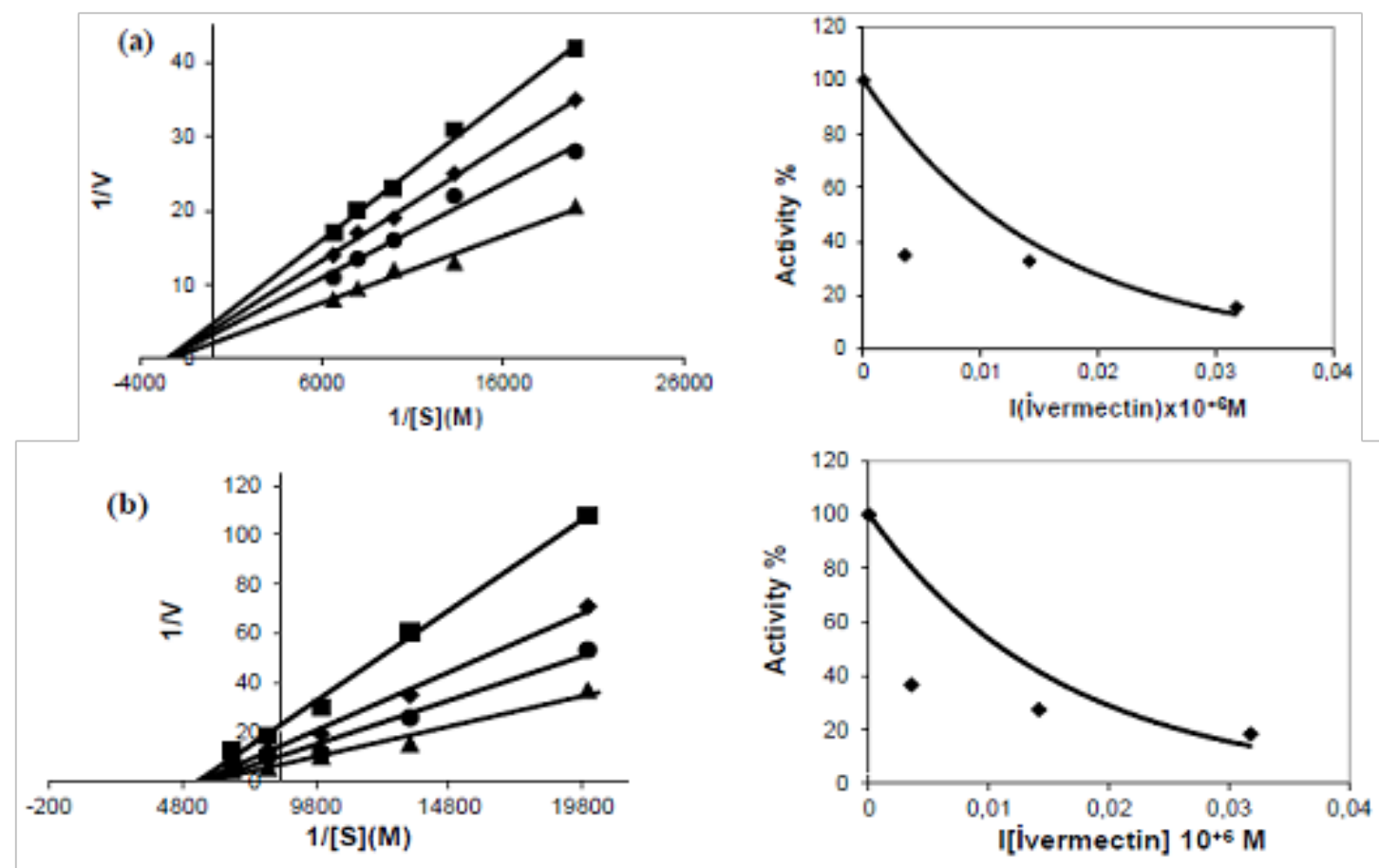

Figure 2. Activity \% vs (drug) regression analysis graphs and Lineweaver-Burk plot of $1 / \mathrm{V}$ vs $1 /[\mathrm{S}]$ in the absence ( $\mathbf{\Delta})$ and presence of 3 different drug concentration for human (a) and erythrocyte (b) plasma AChE.

Table 3. $\mathrm{K}_{1}$ values of plasma AChE were $1.36 \times 10^{-8}$ $\mathrm{M}$ of diclofenac, $1.48 \times 10^{-8} \mathrm{M}$ of ivermectin, $1.56 \times 10^{-8} \mathrm{M}$ of ampicillin, $2.16 \times 10^{-8} \mathrm{M}$ of gentamicin, $804 \times 10^{-8}$ $M$ of clindamycin. $K_{1}$ values of erythrocyte AChE were $0.87 \times 10^{-8} \mathrm{M}$ of kanamycin, $0.99 \times 10^{-8} \mathrm{M}$ of diclofenac, $1.16 \times 10^{-8} \mathrm{M}$ of gentamicin, $1.61 \times 10$ ${ }^{8} \mathrm{M}$ of ivermectin, $3.74 \times 10^{-8} \mathrm{M}$ of clindamycin. Representative graphs are shown in Figure 2 for ivermectin as model. Also, other drugs data are given in Table 3. As shown in Table 3, ivermectin, diclofenac, clindamycin, gentamicin and ampicillin inhibited noncompetitively on human plasma AChE activity. Also, the effect of ivermectin, diclofenac, clindamycin, gentamicin and kanamycin was noncompetitive on human erythrocyte AChE activity. Among these drugs, while ampicillin inhibited plasma AChE, it activated erythrocyte AChE. Like this, although kanamycin inhibited erythrocyte $A C h E$, it activated plasma AChE.

\section{DISCUSSION}

Acetylcholine (ACh), hydrolyzing the carboxylic ester of neurotransmitter acetylcholine (ACh) to afford choline (Chol) and acetic acid (Sch 1), is a neurotransmitter involved in essential brain functions, including memory and learning, thus playing an important role in termination of neurotransmission within cholinergic system $[25,26]$. AChE is the target of many neurotoxins and drugs that specifically binds to its active site [27]. To the best of our knowledge, there are no data concerning the various pharmaceutical drugs used in our study for investigation their inhibition or activation effect on AChE enzyme activity in the literature.

Hence, the effects of the antibiotics (cefazolin, kanamycin, gentamicin, clindamycin, ivermectin, and ampicillin) and the painkiller (metamizole and diclofenac) were investigated as inhibitor or activator on human plasma and erythrocyte AChE. The determining factor of inhibition of the substances on AChE is $I C_{50}$ and $K_{1}$ values. Acetylthiocholine iodide (ATCl) was used as the substrate and 5,5'-dithio-2-bis-nitrobenzoate (DTNB) was used as the chromogen for spectrophotometric assay of AChE activity, which is called Ellman's reaction. In addition, $I_{50}$ values show the dissimilar tendency that diclofenac has the best inhibitory effect on plasma, followed by ivermectin, gentamicin, clindamycin and ampicillin, respectively when gentamicin has the 
highest inhibitory effect on erythrocyte followed by diclofenac, kanamycin, ivermectin and clindamycin, respectively. The values obtained show that these drugs exhibit desirable side effects on AChE activity. It is reported that while gentamicin and kanamycin, aminoglycosides, inhibited AChE; cefazolin, cephalosporins, ampicillin and penicillin caused the inhibition of GABA-A receptors [19]. Stoytcheva and Zlatev found that eserine, nicotinic acid, atropine and caffeine show competitive inhibition and thiamine and quinine noncompetitive show inhibition on AChE activity [28]. To analyze the structure of these active substances, it is seen that active groups of them didn't fit clearly compared to AChE active site. Generally, effect of hydroxyl, amino and oxygen of carbonyl groups are probably connected with the weak bonds to amino acid residues and with outside the active center of the enzyme. It means that these drugs attach to differrent sites of AChE out of the active center of the enzyme, which causes steric effect due to their structures.

As known, enzymes are macromolecules and have isoenzymes in varied tissues and body fluids. Compounds that interact with them cause to change activation of enzyme. The data obtained here show that as the effects of drugs ampicillin, metamizole and kanamycin that link to outside of the enzyme's active site causes the change in the 3-D structure of enzyme. Among these drugs, while ampicillin inhibited plasma AChE, it activated erythrocyte AChE. Like this, although kanamycin inhibited erythrocyte $\mathrm{AChE}$, it activated plasma AChE. The different effect of these drugs on plasma and erythrocyte AChE demonstrates that these isoenzymes can respond to the drugs differentially because of structural difference of the isoenzymes. Thus, these induce alterations in enzyme activity.

\section{CONCLUCIONS}

Here, we investigated in vitro studies of some drugs as inhibitor or activator of the acetylcholinesterase on human erythrocyte and plasma. $I C_{50}$ and $K_{1}$ values of drugs were calculated. As $I C_{50}$ and $K_{1}$ values were $1.78 \times 10^{-8} \mathrm{M}$ and $1.36 \times 10$ ${ }^{8} \mathrm{M}$ for diclofenac which has the best inhibitory effect on plasma, $0.85 \times 10^{-8} \mathrm{M}$ and $1.16 \times 10^{-8} \mathrm{M}$ for gentamicin which has the best inhibitory effect on erythrocyte. As a result, a lot of drugs inhibition types were reversible and noncompetitive.

\section{References}

1. O. Danis, B. Yuce-Dursun, T. Cimen, S. Demir, U. Salan, G. Yalcin, A. Ogan, Evaluation of antioxidant, radicalscavenging and acetylcholinesterase inhibitory activities of various culinary herbs cultivated in southern Turkey, Food Biochem. J., 438 (2001) 602611.

2. A. Spinedi, L. Pacini, P. Luly, A study of the mechanism by which some amphiphilic drugs affect human erythrocyteacetylcholinesterase activity, Biochem. J., 261 (1989) 569-573.

3. B.D. Siegfried, J.G. Scott, Properties and inhibition of acetylcholinesterase in resistant and susceptible German cockroaches (Blattellagermanica L.), Pest. Biochem. Physiol., 38 (1990) 122-129.

4. G.B. Principato, S. Contenti, V. Talesa, C. Mangiabene, R. Pascoloni, G. Rosi, Proprionylcholinesterase from Allobophoracalignosa, Comp. Biochem. Physiol., 94 (1989) 23-27.

5. B.W. Wilson, I.K. Robert, C.K. William, Cholinesterases, in Handbook of pesticide toxicology, Second edition, Academic Press, San Diego, California, USA, 967985, 2001

6. A.A. Al-Qarawi, B.H. Ali, Variations in the normal activity of esterases in plasma and liver of camels (Camelusdromedarius), cattle (Bosindicus), sheep (Ovisaries) and goats (Capra hircus), J. Vet. Med., 50 (2003) 201-203.

7. D. Milatovic, W.D. Dettbarn, Modification of acetylcholinesterase during adaptation to chronic, subacute paraoxon application in rat, Toxicol App. Pharmacol., 136 (1996) 20-28.

8. J. Massoulie, S. Bon, The molecular forms of cholinesterase and acetylcholinesterase in vertebrates, Ann. Rev. Neurosci., 5 (1982) 57-106.

9. D. Nachmansohn, I.B. Wilson, The enzymic hydrolysis and synthesis of acetylcholine, Adv. Enzymol. Relat. Subj. Biochem., 12 (1951) 259-339.

10. V. Chhajlan, D. Derr, B. Earles, E. Schmell, T. August, Purification and partial amino acid sequence analysis of human erythrocyte acetylcholinesterase, FEBS Lett., 247 (1989) 279-282.

11. T.A. Dutta-Choudhary, T.L. Rosenberry, Human erythrocyte acetylcholinesterase is an amphipathic protein whose short membrane-binding domain is removed by papain digestion, J. Biolog. Chem. , 259 (1984) 5653-5660.

12. J. Massoulie, J.P. Toutant, Vertebratecholinesterases: structure and types of interactions, Hand. Exp. Pharmacol., 86 (1998) 167-224.

13. J.,Massoulie, L. Pezzementi, S. Bon, E. Krejci, F.M. Vallette, Molecular and cellular biology of cholinesterases, Prog. Neurobiol., 41 (1993) 31-91.

14. P. Masson, O. Lockridge, Butyrylcholinesterase for protection from organophosphorus poisons: catalytic complexities and hysteretic behavior, Arch. Biochem. Biophys., 494 (2010) 107-120. 
15. X. Chen, L. Fang, J. Liu, C.G. Zhan, Reaction pathway and free energy profiles for butyrylcholinesterasecatalyzed hydrolysis of acetylthiocholine, Biochem. 51 (2012) 1297-1305.

16. E. Giacobini, Cholinesterase inhibitors: new roles and therapeutic alternatives, Pharmacol. Res., 4 (2004) 433-440.

17. S. Snavely, G. Hodges, The neurotoxicity of antibacterial agents, Ann. Intern. Med., 101 (1984) 92-104.

18. K.M. Chow, K.C. Hui, C.C. Szetp, Neurotoxicity induced by beta-lactam antibiotics: from bench to bedside, Eur. J. Clin. Microbiol. Infect. Dis., 24 (2005) 649-653.

19. M.F. Grill, R.K. Maganti, Neurotoxic effects associated with antibiotic use: management considerations, $\mathrm{Br}$. J. Clin. Pharmacol., 72 (2011) 381-393.

20. K. Chow, C.C. Szeto, A.C. Hui, P.K. Li, Mechanisms of antibiotic neurotoxicity in renal failure, Intern. J. Antimic. Age., 23 (2004) 213-217.

21. E. Edward, M.D. Morse, Toxic effects of drugs on erythrocytes, Ann. Clin. Sci., 18 (1988) 13-18.

22. M. Erat, M Ciftci, In vitro effects of some antibiotics on glutathione reductase from sheep liver, J. Enzym Inhib. Med. Chem., 18 (2003) 545-550.
23. S.O. Kayaalp, Rasyonal Tedavi Yönünden Tıbbi Farmakoloji, Hacettepe-Taş pressing, Ankara, Türkiye, 1998.

24. G.L. Ellman, K.D. Courtney, V. Jr. Andres, R.M. Featherstone, $A$ new and rapid colorimetric determination of acetylcholinesterase activity, Biochem. Pharmacol., 7 (1961) 88-95.

25. A.M. Siebela, E.P. Rico K.M. Capiotti, A.L. Piato, C.T. Cusinato, T.M.A. Franco, M.R. Bogo, C.D. Bonan, In vitro effects of antiepileptic drugs on acetylcholinesterase and ectonucleotidase activities in zebrafish (Danio rerio) brain, Toxicol. Vitr., 24 (2010) 1279-1284.

26. I. Shaked, G. Zimmermann, H. Soreq, Stress-induced alternative splicing modulations in brain and periphery, Ann. New York Aca. Sci., 1148 (2008) 269281.

27. E. Milkani, C.R. Lambert, W.G. McGimpsey, Direct detection of acetylcholinesterase inhibitor binding with an enzyme-based surface plasmon resonance sensor, Anal. Biochem., 408 (2011) 212-219.

28. M. Stoytcheva, R. Zlatev, Bioelectrocatalytical studies of the effect of some pharmaceuticals on the acetylcholinesterase activity, Electroanalys., 8 (1996) 676-679. 